This item was submitted to Loughborough's Research Repository by the author.

Items in Figshare are protected by copyright, with all rights reserved, unless otherwise indicated.

\title{
Representing valued bodies in PE: a visual inquiry with British Asian girls
}

PLEASE CITE THE PUBLISHED VERSION

http://dx.doi.org/10.1080/17408989.2012.690381

PUBLISHER

Routledge (@ Association for Physical Education)

VERSION

SMUR (Submitted Manuscript Under Review)

LICENCE

CC BY-NC-ND 4.0

REPOSITORY RECORD

Hill, Joanne L., and Laura Azzarito. 2019. "Representing Valued Bodies in PE: A Visual Inquiry with British Asian Girls”. figshare. https://hdl.handle.net/2134/11720. 
This item was submitted to Loughborough's Institutional Repository (https://dspace.lboro.ac.uk/) by the author and is made available under the following Creative Commons Licence conditions.

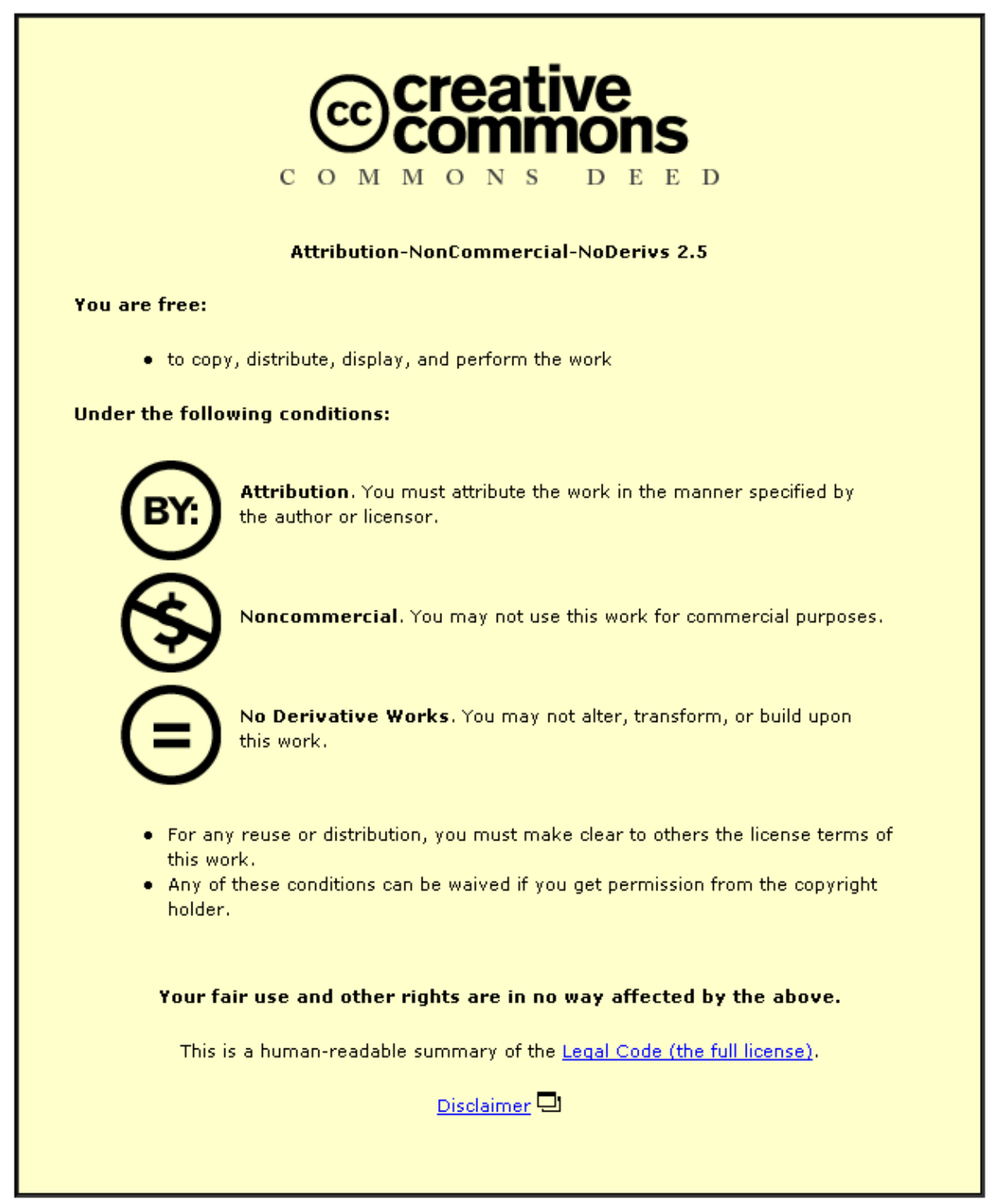

For the full text of this licence, please go to: http://creativecommons.org/licenses/by-nc-nd/2.5/ 
Notice: This is the author's version of a book review published in Sport, Education and Society, 2012 (17:3, 263-276). The review appears here in its pre-publication format in lieu of the publisher's version of record. The published review can be found at http://www.tandfonline.com/doi/abs/10.1080/17408989.2012.690381

Representing valued bodies in PE: a visual inquiry with British Asian girls

\author{
Joanne Hill, MA ${ }^{1}$ \\ Laura Azzarito, PhD $^{2}$ \\ ${ }^{1}$ Loughborough University, UK \\ ${ }^{2}$ Columbia University, USA
}

Corresponding author:

Joanne Hill

School of Sport, Exercise and Health Sciences

Loughborough University

Loughborough LE11 3TU

Phone +44 (0)1509 228779

Email: j.hill@lboro.ac.uk

Key words: embodiment, girls, ethnicity, visual methods, identity 


\section{$1 \quad$ Abstract}

2 Background: Status or value in sport and physical education (PE) contexts is often associated 3 with performances of highly proficient sporting bodies (Shilling, 2008), which produce 4 hierarchies of privileged and marginalised gendered and racialised positions. This may be 5 communicated through text and images shared within school, physical cultures and media 6 that young people consume. Understanding how students make sense of constructions of 7 valued bodies in PE, and how this affects their sense of self, can assist in creating spaces for 8 young people to experience alternative narratives.

9 Focus: The paper's aims are to explore varying ways British Asian girls visualise and make 10 sense of themselves as active or sporting bodies, and what this means for their 11 (dis)engagement in physical activity.

12 Theoretical framework: This study draws on a feminist poststructuralist approach (Davies \& 13 Harré, 1990; Weedon, 1997) concerning the ways in which young people create multiple 14 subject positions through negotiating or rejecting verbal and visual narratives about physical 15 activity and girlhood.

16 Methods: The data draws from a one-year collaborative visual ethnography conducted with 1725 students aged 13-14 in a predominantly British Asian urban secondary school in the UK. 18 In this research, student-participants were included in the data production through being 19 asked to create photographs over a two-week period that represented their views of valued 20 bodies in physical activity contexts in and out of school. Focus group interviews used 21 participant-driven photo elicitation techniques to talk through the images (Clark, 1999). 22 Findings: In this paper, two British Asian girls' photos enabled them to talk about, analyse, and reflect on valued or sporting bodies that they saw in visual media. The girls illustrated their performances of constrained or empowered physicalities, within a physical culture that values, among girls, racialised performances of active but feminised bodies. Many girls placed their physical activity significantly in school, and saw sporting bodies as male and elite. Where students do not associate people like themselves as sporting bodies, there may be implications for their continued involvement in physical activity. At the same time, girls were physically activity outside of school despite not seeing themselves as sporty. Reflecting on the invisibility of minority ethnic women in sports media, this research suggests that greater representation may enable young minority women to see themselves and people like them as valued bodies in sport and physical activity. 
Valued bodies in sport pedagogy

Status or value in secondary PE contexts is often associated with performances of

highly proficient sporting bodies (Shilling, 2008), given the continuing predominance of "traditional", team, competitive sports in PE curricula and the centrality of corporeal performance in sport. Research on youth sport and PE finds that outcomes desired in sport put value on the display of specific normative body appearance and behaviour of proficient sporting bodies, producing hierarchies of privilege and marginality (Azzarito \& Solmon, 2006; Hills, 2006; McCaughtry \& Tischler, 2010; Oliver \& Lalik, 2000; Shilling, 2008). Definitions of sporting bodies vary; in PE research, conferring privilege or status to bodies that perform appropriately either on and off the pitch in terms of ability (Evans, 2004; Hay \& Macdonald, 2010; Redelius et al, 2009; Wright \& Burrows, 2006), strength (Bramham, 2003; Hauge \& Haavind, 2011; Parker, 1996), or muscularity (Gorely et al, 2003). The notion of "valued bodies" is useful to explore the ways in which certain bodily appearances and performances/actions attain high status because of their value within a social context such as a physical culture or PE context (Redelius et al, 2009; Wright \& Burrows, 2006).

These narrow ranges of value are stratified along intersections of gender, race, class and age. In today's public health context, certain cohorts of young people are more likely than others to be identified as having "bodies-at-risk", a discourse that fixes and homogenises minority young people identities as "different", unhealthy and physically inactive. Evidence from national reports in the UK indicates that "Other" girls, such as those from South Asian backgrounds, with low socio-economic status or with disabilities, have been identified as the least physically active and having the worst health status (Sporting Equals, 2007; Long, Hylton, Spracklen, Ratna and Bailey, 2009). Rather than valued bodies - bodies that are healthy, sporting, physically active - "different" bodies are presented as "deviant" from 
2008; Harris, 2004; Johnson, 2000; Ramanathan \& Crocker, 2009). The cultural relationship between hegemonic masculinity and performances of proficient and strong sporting bodies (Connell, 1987, 1995; Wellard, 2006) simultaneously marks female sporting bodies as unfeminine (Cockburn \& Clarke, 2002) or associates women's physical activity with maintenance of a "not too muscley", shapely and aerobicised appearance (Gorely et al, 2003; Markula, 1995).Theoretical framework

Feminist poststructuralism can add to understandings of how discourses surrounding what is and is not valued can be taken up and negotiated by young people in the construction of their identities (Weedon, 1997). Only subjectivities made possible in discourse can be taken up (Davies, 2004). Identities and subjectivities are formed in relation to the discourses and images (Wright, 2004) that young people encounter and (re)produce within institutional and media sites. By "positioning” (Davies \& Harré, 1990) oneself in relation to the discourses available within a culture or social field, individuals become embodied by practising or living out discourses. Rail (2009: 143) uses a poststructuralist framework to conceptualise positioning as how the 'gendered, heterosexualised and racialised discourses to which one has access' provide spaces that individuals can inhabit or codes by which they can act, behave and perform in social practices. These rationales 'make available different modes of relating to the self, and lived relations of the body' (O'Flynn, 2008: 110). To this poststructuralist approach, postcolonial feminist scholarship adds that inquiry on the body must rethink assumptions of Whiteness, as the privileging of white peoples, knowledge and experience, perceiving them as universal (Frankenberg, 1993), in the ways bodies are able to move, behave and look, which is of especial pertinence in activity contexts. This perspective can aid researching the intersecting gendered and racialised discourses to which young women have access to construct meanings and position their selves (van Sterkenberg \& Knoppers, 2004). Many studies on young women and physical activity address gender 
constructions and relations; ethnicity and race in intersection with gender must also be the focus of study (Brah, 1996; Flintoff et al., 2008), for racialised discourse and practice have an impact on the physical active body.

Engagement with visual cultural resources through sports media, spectatorship and participation may inform or illuminate students' participation in school PE and the impact on young people's physical identity or sense of self from constructions of valued bodies. This is of keen importance especially in today's image-heavy, postmodern and individualised world where self-worth and one's place in society are closely tied to the self-managed, but fluid, body (Shilling, 2003, 2008; Turner, 2008). Tinning and Fitzclarence (1992) and Wright (2004) suggest that young people learn through their engagements with popular or physical culture, media and institutional sites and make meanings for their bodies that are relevant to their readings of popular culture. Together, the consumption of many ideal bodies in visual culture and the gaze of others put the body under examination. Visual cultures within schools may be a part of the hidden curriculum, as resources for teaching that are not explicitly planned for lessons (Harrison, Azzarito \& Burden, 2004; Prosser, 2007). Research on both PE and wider schooling contexts has previously made use of the concept of the hidden curriculum to describe how students learn implicit, subconscious knowledge that reproduces certain values or dominant interests, which may explain how inequalities are enforced, especially in unconscious communication (Fernandez-Balboa, 1993; Kirk, 1992). The discourses and images constituting a visual or physical culture can offer students fixed ways of thinking about and visualising their own and others' bodies as valued or unvalued.

A physical culture in PE that valorises particular sporting bodies in gendered and racialised ways may have a negative impact on young people who are unable to conform to producing a sporting or normative body, do not gain status, and who feel excluded or marginalised in PE. Some studies have explored the practices or processes of negotiating 
108 embodied identities in secondary school PE in first world countries, considering the PE 109 classroom to be a site for empowerment through knowledge of the body, providing

110 opportunities for young people to construct their own meanings of their identities and

111 deconstruct dominant notions of sporting or ideal bodies (Armour, 1999; Fisette, 2011;

112 Garrett, 2004; MacNeill \& Rail, 2010; O’Flynn; 2008). Researching intersectionality of

113 gender/race/class in PE, sport and leisure has become crucial in understanding diversity

114 among young people and their engagements with physical cultures (Atencio, 2008;

115 Fitzpatrick, 2011; Flintoff, Fitzgerald \& Scraton, 2008; George \& Rail, 2005; Scraton,

116 Caudwell \& Holland, 2005; Scraton \& Watson, 1998; Rail, 2009; Wright, 2006).

117 In particular, research on South Asians' experiences in sport finds that they constitute

118 identities and spaces for themselves among discourses of values, locations of and access to

119 competitive sport (Scraton et al, 2005; Ratna, 2010); "Indo-Pak" masculine identities in

120 recreational sport are formed in relation to Blackness and Whiteness (Thangaraj, 2010), while

121 the cooptation of "stylish hybridity" by mass media and consumerism has been critiqued

122 (Giardina, 2003). Asians are presented as structurally and discursively marginalised in some

123 sports, including football in the UK (Burdsey, 2007; Crozier \& Davis, 2008; Elling \&

124 Knoppers, 2005; Fleming, 1991). A perception of Asian young people's low skill or

125 submissive and frail bodies results in assumptions that they are little interested in sport, or

126 that sporting bodies are not valued in Asian communities (Bramham, 2003; Fleming, 1991;

127 Lewis, 1979; Lovell, 1991). Data is needed on whether there are multiple ways in which

128 bodies come to be valued in diverse young people's physical cultures and what impact local

129 context, such as a school physical culture, may have on young people visualising themselves

130 as valued sporting or active bodies. 
133

134

135

136

137

138

139

140

141

142

143

144

145

146

147

\section{Participatory visual ethnography}

This inquiry's design combined ethnography with participant-driven visual data to explore the meaning-making and practices associated with the discursive construction and visualisation of value and status for bodies in secondary PE lessons. To be critical about the meanings young people negotiate, we need to engage both with textual/verbal and visual discursive sources (Azzarito, 2010; Phoenix, 2010). Some research on bodies in PE has centred on surveillance of movements, appearances and interactions, indicating that a visual approach to studying PE classes and young people's experiences within them is important (Cockburn \& Clarke, 2002; Fisette, 2011; Gard \& Meyenn, 2000; Wright, 1995). Acknowledging that 'simply interviewing students ... is insufficient for understanding the complexities and nuances of their worlds', (Oliver, Hamzeh and McCaughtry, 2009: 96), visual methods are a strategy incorporated into interpretive research with young people that can provide both verbal and visual engagement. Three strands have developed in the use of visual methods: researcher-created or collected images; participant-created, existing images; and participant and researcher collaboration in the creation of images (Banks, 2007; Thompson, 2008). Taking up an epistemology that promotes situated knowledges and where researcher and participants co-construct knowledge through interaction (Haraway, 1990), this research combined collaborative data production with design informed by the principles of visual ethnography.

Ethnographic research can uncover the complexity of social settings, understanding that emplaced and embodied knowledge and experience is co-constructed among participants and researcher (Guba \& Lincoln, 2005; Pink, 2007, 2009). The turn to research with, rather than on, young people and children, that seeks to address power relations has led to greater participatory or collaborative work (Christensen \& James, 2000), acknowledging that young people are active agents able to invest in research and to interpret and negotiate discursive 
158 messages (Greene \& Hill, 2005). Young people's perspectives on images and visual cultures

159 are necessary to deprivilege adult understandings of the body, provide insights into corporeal

160 meanings and make visible the norms and values of the hidden curriculum (Oliver \& Lalik,

161 2000; Prosser, 2007). Giving participants control over producing visual data can encourage

162 involvement with a project. Although the participants here were not involved in the design of

163 the study, they were able to select from their worlds the people, places and activities they

164 wished to share.Photo-elicitation from researcher-produced or collated images (Azzarito \&

165 Solmon, 2006) and increasingly from participant-produced photographs (Azzarito \& Sterling,

166 2010; Pope 2010) and drawings (Mowling, Brock \& Hastie, 2006; MacNeill \& Rail, 2010)

167 has offered alternative ways of engaging young people in sharing non-verbal embodied

168 experiences. Ethnographic studies with long-term engagement in a PE context have also

169 become common (Fitzpatrick, 2011; Enright \& O'Sullivan, 2011) for their 'capacity ... to

170 capture a sense of the relationship between individuals, differences between them, and their

171 perceptions of the discourses and practices that occur in different social fields' (Hills, 2006:

172 544). Long and Carless (2010: 216) suggest that "alternative" or creative methods may help

173 to 'include the experiences - and therefore 'voices' - of individuals who might otherwise fail

174 to be represented within more traditional interview methods'. At the same time, the voices

175 heard through visual methods are not perceived to be more authentic or to uncover any

176 "truer" identity or reality (Gauntlett \& Holwarth, 2006) than through verbal methods, but a

177 combined verbal and visual approach may enable researchers to think differently about the

178 experiences that are communicated by participants (Buckingham, 2009; Phoenix, 2010).

179 Setting and participants

180 This study took place in one urban secondary school site in the East Midlands, UK,

181 with an ethnically diverse student population that was 80 percent British Asian. Students

182 were timetabled for two hours of PE lessons per week. Year 9 (age 13 to 14) classes were 
183 chosen for the research in consultation with the PE teachers. The research participants were

184 drawn from four PE classes: two girls' and two boys' classes of around 30 students each. The

185 school was mixed (co-ed) but PE lessons were gender-segregated. Research observations ran

186 throughout the school year from October to May. A number of weeks into the observation

187 period, all students from both classes were informed about the focus of the study and were

188 invited to join the participatory elements of the project. 25 students volunteered to participate

189 (14 boys, 11 girls; 20 British Indian, two white, one black African, one Asian-African and

190 one Anglo-Asian).

191 Data collection

192 A number of sources of data were used: field notes, group interviews, participants'

193 photography and researcher's photography. Group interviews were carried out in single sex

194 groups, to mirror the structure of the participants' PE classes. Identified as a potentially

195 feminist method (Wilkinson, 1999), group interviews were deemed to offer ways of

196 reproducing some of the social interactions and peer dynamics among the students, and

197 ethically to assuage some of the researcher's authority and put the young people more at ease.

198 In the first interviews, the participants discussed their experiences in physical activity and the

199 ways that bodies become admired or valued in PE. Following these group interviews, each

200 participant was given a digital camera for a fortnight and asked to create photos recording (1)

201 what do you do when you're (not) being active? (2) what sorts of bodies are valued in your

202 PE class, sports club or peer group? All participants were instructed in use of the camera's

203 major functions including flash, zoom, exposure length and colour. They were permitted to

204 delete any photos they did not want to share. At the end of the fortnight, cameras were

205 collected by the researcher, all photographs uploaded and printed on gloss paper. Second and

206 third rounds of group interviews were structured around photo elicitation techniques (Clark,

207 1999; Harper, 2002) whereby questions assisted participants in explaining the meanings of 
208 their photos and the representations they offered of their experiences of physical activity

209 during the fortnight with the camera. Field notes created by the researcher aimed to provide

210 contextual data of the school community.

211 Analysis

212 In categorising the data, an iterative approach of multiple layers of coding (Bryman,

213 2008; Coffey \& Atkinson, 1996) was used to inductively and deductively categorise. Coding

214 began line-by-line using emic themes and language. A content analysis of the images further

215 noted people, place and activity (Wright, 2004; Rose, 2012), however the participants'

216 photographs and interviews were viewed and coded side by side avoided removing the

217 images from their verbal explanations. Where students used their photos to explain their

218 verbal narratives, this highlighted themes surrounding how sporting or active bodies were

219 visualised, which individuals could gain status in sport or PE and students' ways of 220 positioning themselves with or against locally dominant values. All names used in this paper 221 are pseudonyms.

\section{Findings}

Of the 14 girls involved in the research, only three were active in organised competitive sports outside of school. A vast majority of the photographs (156 of a total 195) of the photographs that the girls created to answer "what do I do when I'm being active?" were taken inside the school, specifically in PE lessons or after-school sports clubs, reflecting the centrality of school-based physical activity in their lives. In interview however, many of the girl participants reported their engagement with recreational activities, raising questions about their means to articulate physical activity participation.

As part of the field work, notes were kept of the visual media lining the walls of the

232 PE corridor, including posters, notices and sports club advertisements. During the interviews, 
233 girls discussed their responses to the images in the PE corridor, noting that they contemplated

234 the messages communicated through this medium. Literature on the hidden curriculum

235 suggests that the visual culture of a school, especially where PE departments display images

236 of bodies engaged in activities, inform students which bodies are valued within the school,

237 and hence which bodies can legitimately participate (Prosser, 2007). A number of these

238 posters displayed elite athletes engaged, often competitively, in a number of sports. Over half

239 the posters portrayed white men. Only one portrayed women of colour and no Asian women

240 were represented in the posters. As such, legitimate sporting bodies promoted in the school

241 site were embedded in Whiteness. That is, greater visibility in school poster displays was a

242 marker of greater legitimacy for bodies in sport; Birrell and Theberge (1994) noted similar

243 with respect to women's sport as a whole. This context provides a useful starting point for

244 considering how some girls articulate their embodied identities as active or inactive as they

245 negotiate and challenge dominant constructions of valued sporting and racialised feminine

246 bodies. Photographs, and accompanying explanations, have been selected from two girls'

247 photo diaries.

248 Bhavana

249 Bhavana was a highly active, confident and competent mover in PE. She was also a

250 black belt in Tae Kwon Do which she participated in outside of school. Bhavana used two

251 images of black males to illustrate her conceptualisation of valued bodies (an Olympic

252 sprinter who is at the pinnacle of sporting success; and a teacher who is valued for supporting

253 students). Black males here seem to be central to Bhavana's understanding of people who are

254 involved in sport while girls like her are represented as passive or inactive. She photographed

255 her brother demonstrating Tae Kwon Do moves as an example of an active, skilled and

256 disciplined body (Figure 1). However, she does not photograph herself doing the same

257 despite her own achievements in this sport. To represent her taekwondo participation, 
258 Bhavana laid her kit out on the floor (see Figure 2), not even wearing it to pose in or to create

259 photos similar to those showing her brother. The only time she was visible in the photo set

260 was in a self-portrait. Bhavana explained that this photo answered "what I do when I'm not

261 active". Bhavana is an example of many girls in the project who did not include themselves

262 in photos. The photography instruction sheet given to the students advised that it was

263 acceptable for them to hand the camera to a friend in order to take photos of themselves, if

264 they wished. While the lack of self-photos may at times have been a technical issue - no one

265 around to take photos - in those instances where friends and family are photographed in

266 action, as we see Bhavana's brother, it would have been simple for the photographer and

267 subject to switch roles. Bhavana (and others) chose not to do this. This young woman met

268 with few images within the school space of girls like her as active or sporting bodies.

269 Bhavana was confident and able in PE and active in martial arts outside school, but where

270 South Asian girls' bodies were invisible in the physical culture, her perception of herself was

271 affected such that she did not represent herself as active in her photos - making herself

272 invisible in her photo set apart from through the ideal femininity portrayed in her self-portrait

273 photo.

Figures 1, and 2 here

Meena

Meena also offered an important insight into the ways students' embodied subjectivities and activity participation could be affected. For Meena, Olympic athletes represented the sporting bodies that she admired. She talked about being inspired by watching the Olympic Games on the television: 
you can imagine yourself there but then you realise like I don't go anywhere, I've got to go and join a club first. (Meena)

Measures of status included exposure on television: because Meena only saw men's sport on

television, she saw men as more naturally suited to sport:

You watch telly and then you always see like in football they are always um, men playing football and men playing rugby so it's like, and cricket and all that, but you hardly see like women and girls playing all those sports, so it's like, it's just naturally suited for [men]. (Meena)

While Meena suggested that she might, in the future, take up a sport in a competitive way, it really has little relevancy to her life and self as she constructed herself here. She positioned herself as different to the competitive sporting bodies she recognised in the Olympics and media sport cultures. Although Meena said that she enjoyed watching elite athletes, her sense of herself as articulated in her photo diary and interviews was not informed by being a sports person. Meena reported that outside of PE she was not very active. In PE lessons, she did not resist participating, but neither considered herself to have high ability. Here emphasis is added to highlight how her language suggests she's not interested in sport but she thinks other people might be:

They've got different sports so that there's something for everyone and it could like possibly make others want to go and join the sport because it's so much variety so it's like, um, you might go and join a club after you've done the sport in PE. (Meena)

Meena seemed unable to speak of herself as a sporting body. In Meena's set of 26 photos, she emphasised seven that showed large groups of male students on the playing fields engaged in football and running games at break times (see Figure 5). Photos of Meena and her friends displayed them chilling out at lunchtimes, posing for the camera (Figure 6). In line with her admiration for Olympic athletes, Meena explained that both her friends and the boys at school are to be admired because they are committed to sports participation in extracurricular clubs at school. She discussed the support and team work she valued from them in 
311 PE and their recreational dance activities at home. She perceived her friends as being active

312 in extra-curricular sports clubs at school, but resisted joining in with them, claiming that she

313 had other hobbies, including Art Club, that she preferred over sports.

$314 \quad$ Figures 3 and 4 here

315 The only activity that prompted Meena to talk animatedly was dancing with her

316 friends at home. She talked about making up routines and teaching each other new moves,

317 just to perform to each other in the home. She said,

322

It builds up my confidence and before I don't think I was really confident, but after I'd taken up dancing I used to um perform everywhere and I've learn the actual dance and everything. I think my confidence has gone up and I think it helps me to do things other than dance as well. Sometimes. (Meena)

Dancing, and particularly the performance of dancing, offered Meena confidence that she uses in other aspects of her life. Some girls talked about leisure/recreational spaces and activity forms (such as dancing) as being free and offering emotional satisfaction and kinaesthetic pleasure. As Atencio (2008) argues, alternative cultures or styles of, in this case, dance, can enable young women to avoid the disciplinary practices of dominant white culture. This contrasts with the space of the school wherein behaviour and movements are monitored by teachers, activities are constrained by certain objectives and students feel watched at all times. Students invest in the forms of activity that give them this sense of freedom, pleasure and positivity. Meena felt ambiguous about any connection between her physicality in expressive activities such as dance and the physicalities of her sportier friends. Although Meena did what was expected of her in PE, her experiences suggest that she simultaneously resisted subjectivity as a competitive sports player while promoting cooperative situations such as dance.

Meena's "sport is not for me" stance can also be seen in the way she spoke about sport as not being an acceptable career path for people of a certain background: 
It's like different types of people expect different things, so like some people who um, say if for example, weren't educated and they want to educate their kids as far as they can, and they don't want to take the risk that oh, if they go round doing sports then what are they going to earn later on? So I think it's a bit like that. (Meena)

While she did not explicitly refer to British Asian or another specific ethnicity, using instead indicators of class or socio-economic background, Meena's speech recalls the common notion that British Asian parents want their children to be doctors or lawyers, devaluing sport if it has no academic or career use (Ramanathan \& Crocker, 2009; Strandbu, 2005). Meena, while talking impersonally, may have been positioning herself and her family as devaluing sport as a career. Some of the ways in which sport was constructed in the school physical culture led Meena to think that an investment in sport means a large commitment, a life of sport and aiming for a high level of success in it. Participation-level or recreational engagement were not associated with valued sporting endeavours.

\section{Discussion}

While some measures were identified among teachers as attempts to increase girls' participation in PE and school sport, such as allowing freer interpretation of the PE kit rules; including traditionally female activities on the curriculum; and dividing PE into single sex classes, there appeared a divide between the recreational, school-level activities that were available for girls, and engagement in higher levels of sport that was reserved for male athletes. Theories of discursive practice (Weedon, 1997; Davies, 1989), visual culture (Prosser, 2007) and hidden curriculum (Kirk, 1992) highlight that the dominant visual messages offered within the school space affected these girls' constructions of themselves as active or sporting.

With girls such as Meena positioning sports as predominantly for boys, images displayed throughout the school rarely offered an alternative visualisation of girls' legitimate place in physical activity. Although it is clear that not all young people will become 
364 successful in competitive sport, findings here suggest a link between the visuality and 365 legitimacy of elite female athletes and girls' positioning of themselves as active or sporting 366 bodies. Yet among these narratives suggesting Asian students' low ability and engagement in 367 physical activity, it is also evident that these girls were active outside of school, that despite 368 the construction of girls like them as inactive, they were able at other times to resist. Young 369 people's own body narratives give them the ability to make multiple readings of bodies that 370 they encounter in educational or media sites (Atencio, 2008; Davies, 2004; van Sterkenburg $371 \&$ Knoppers, 2004). The school physical culture appeared to offer few alternative narratives 372 for producing subjectivities, so that within the meanings the girls had available to them, they 373 did not define their recreational engagement as sporty. Yet outside of school, the girls found 374 meanings that enabled them to engage in physical activity and thus resist notions of Asian 375 girls and women as passive and physically inactive (Fleming, 1991; Lovell, 1991). Bhavana and Meena became involved in, respectively, taekwondo and dance through female friends or

377 family members, who did represent active minority ethnic women. Peer and family networks 378 have been found important for minority girls' recreation (Scraton \& Watson, 1998). This paper has explored a number of the ways that young women visualised valued bodies and their active or inactive embodied identities within PE contexts. By interrogating the discourses that educational institutions are offering to young people through the hidden curriculum, ways can be found to deconstruct assumptions of Whiteness in the ways sporting and gendered bodies are given value in school sites (Wright, 1995). This paper is part of a broader study that engaged a diverse group of young people in visual and verbal methods of data production to investigate their physical activity practices in the context of their diverse, urban secondary school. If researchers and teachers are committed to deconstructing

387 Whiteness that is embedded in the visual physical cultures of activity spaces, and which 388 informs how bodies may be valued in schools, participatory visual methods within 
389 ethnographic studies have the potential to enable highlighting the complexity of young

390 people's meanings of their selves in culturally and gender sensitive ways (Vertinsky, 1992).

391 Although Bhavana and Meena were participants in physical activity, if they do not position

392 themselves as active within the discourses defining what active means there may be

393 implications for their continued engagement (Garrett, 2004b). Given the increasing

394 importance placed on competition in school sport and at the same time lifelong activity, a

395 commitment to representing diversity among elite sports players may assist objectives to

396 increase young people's engagement. Young people are able to verbalise and visualise what

397 valued bodies mean to them. If they are given potential to create alternative narratives and

398 selves within educational settings they may have more space to articulate and experience

399 active identities.

400

$401 \quad$ References

402

403

404

405

406

407

408

409

410

411

412

413

414

415

416

417

Armour, K. 1999. The case for a body-focus in education and P.E. Sport, Education and Society, 4, 515.

Atencio, M. 2008. 'Freaky is just how I get down': investigating the fluidity of minority ethnic feminine subjectivities in dance. Leisure Studies, 27(3), 311-327.

Azzarito, L. 2010. Future girls, transcendent femininities and new pedagogies: toward girls' hybrid bodies? Sport, Education and Society, 15(3), 261-275

Azzarito, L. and M. Solmon. 2006b. A feminist poststructuralist view on student bodies in physical education: sites of compliance, resistance and transformation. Journal of Teaching in Physical Education, 25, 200-225.

Azzarito, L. and J. Sterling. 2010. 'What it was in my eyes': picturing youths' embodiment in 'real' spaces, Qualitative Research in Sport and Exercise, 2, 2, 209-228.

Banks, M. 2007. Using visual data in qualitative research. London: Sage.

Brah, A. 1996. Cartographies of diaspora: contesting identities. London: Routledge.

Bramham, P. 2003. Boys, masculinities and PE. Sport, Education and Society, 8, 57-71.

Buckingham, D. 2009. Creative visual methods in media research: possibilities, problems and proposals. Media Culture Society, 31, 633-652. 
Burdsey, D. 2007. British Asians and football: culture, identity, exclusion. Oxford, Routledge.

Christensen, P. and A. James. 2000. Childhood diversity and commonality: some methodological insights. In P. Christensen and A. James (Eds..), Research with children: perspectives and practices. London: Falmer Press.

Clark, C. D. 1999. The auto-driven interview: a photographic viewfinder into children's experiences. Visual Sociology, 14, 39-50.

Cockburn, C. and G. Clarke. 2002. "Everybody's looking at you!": girls negotiating the "femininity deficit" they incur in Physical Education. Women's Studies International Forum, 25, 651-665.

Connell, R. 1987. Gender and power. Cambridge: Polity Press.

Connell, R.W. 1995. Masculinities ( $2^{\text {nd }}$ ed.). Cambridge: Polity Press.

Crozier, G. and J. Davies. 2008. 'The trouble is they don't mix': self-segregation or enforced exclusion? Race, Ethnicity and Education, 11:3, 285-301.

Davies, B. 1989. The discursive production of the male/female dualism in school settings. Oxford Review of Education, 15(3), 229-243.

Davies, B. and R. Harré. 1990. Positioning: the discursive production of selves. Journal of the Theory of Social Behaviour, 20. 43-65.

Elling, A. and A. Knoppers. 2005. Sport, gender and ethnicity: practises of symbolic inclusion/exclusion, Journal of Youth and Adolescence, 34(3), 257-268.

Enright, E. \& M. O'Sullivan. 2011. 'Can I do it in my pyjamas?' Negotiating a physical education curriculum with teenage girls. European Physical Education Review, 16(3), 203-222.

Evans, J. 2004. Making a difference? Education and 'Ability' in Physical Education, European Physical Education Review, 10(1), 95-108

Evans, J., E. Rich, B. Davies, and R. Allwood. 2008. Education, disordered eating and obesity discourse. fat fabrications. Abingdon: Routledge.

Fernandez-Balboa, J-M. 1993. Sociocultural characteristics of the hidden curriculum in physical education., Quest, 45, 230-254.

Fisette, J.L. 2011. Exploring how girls navigate their embodied identities in physical education, Physical Education \& Sport Pedagogy, 16: 2, 179-196.

Fitzpatrick, K. 2011. Stop playing up!: Physical education, racialization and resistance, Ethnography, 12(2), 174-197.

Fleming, S. 1991. Sport, solidarity and Asian male youth culture. In G.Jarvie (ed.), Sport, Racism and Ethnicity, London: Falmer Press.

Flintoff, A., H. Fitzgerald and S. Scraton. 2008. The challenges of intersectionality: researching difference in physical education. International Studies in Sociology of Education,18:2,73 85 
Frankenberg, R. 1993. White women, race matters: the social construction of whiteness. Minneapolis: University of Minnesota Press.

Gard, M. and R. Meyenn. 2000. Boys, bodies, pleasure and pain: interrogating contact sports in schools. Sport, Education and Society, 5, 19-34.

Garrett, R. 2004. Negotiating a physical identity: girls, bodies, and physical education. Sport, Education and Society, 9, 223-237.

Gauntlett, D. and P. Holzwarth. 2006. Creative and visual methods for exploring identities. Visual Studies, 21(1), 82-91.

Giardina, M. 2003. 'Bending it like Beckham' in the global popular: stylish hybridity, performativity, and the politics of representation, Journal of Sport and Social Issues, 27(10), 65-82.

George. T. and G. Rail. 2005. Barbie meets the bindi: discursive constructions of health among young South-Asian Canadian women, Women's Health and Urban Life, 4(2), 44-66.

Gorely, T. R., Holroyd and D. Kirk. 2003. Muscularity, the habitus and the social construction of gender: towards a gender relevant physical education. British Journal of Sociology of Education, 24, 429-448.

Greene, S. and M. Hill. 2005. Researching children's experience: methods and methodological issues. In S. Greene and D. Hogan (Eds..).Researching children's experience: methods and approaches. London: Sage.

Guba, E. and Y.S Lincoln. 2005. Paradigmatic controversies, contradictions, and emerging confluences. In N.K. Denzin and Y. S. Lincoln (Eds..).Handbook of qualitative research ( $3^{\mathrm{rd}}$ ed.). London: Sage.

Haraway, D. 1990. Situated knowledges: the science question in feminism and the privilege or partial perspectives. Feminist Studies, 14(3), 575-599.

Harris, A. 2004. Jamming girl culture: young women and consumer citizenship, in: A. Harris \& M. Fine (Eds..).All about the girl. Culture, power, and identity, London, Routledge.

Harper, D. 2002. Talking about pictures: a case for photo-elicitation. Visual Studies, 17(1), 13-26.

Hauge, M. and H. Haavind. 2011. Boys' bodies and the constitution of adolescent masculinities., Sport, Education and Society, 16(1), 1-16

Hay, P. J. and D. Macdonald. 2010. Evidence for the social construction of ability in physical education, Sport, Education and Society, 15(1), 1-18.

Hills, L.A. 2006. Playing the field(s): an exploration of change, conformity and conflict in girls' understandings of gendered physicality in physical education. Gender and Education, 189(5), 539-556.

Johnson, M.R.D. 2000. Perceptions of barriers to healthy physical activity among Asian communities. Sport, Education and Society, 5(1), 51-70.

Kay, T. 2006. Daughters of Islam: family influences on Muslim young women's participation in sport. International Review for the Sociology of Sport, 41, 357-373. 
Kirk, D. 1992. Physical Education, discourse, and ideology: Bringing the hidden curriculum into view. Quest, 44, 35-56.

Lewis, T. 1979. Ethnic influences of girls' physical education. The British Journal of Physical Education, 10(5), 5.

Long, J. and D. Carless. 2010. Hearing, listening and acting. In M. O'Sullivan and A. MacPhail, (eds.).Young People's Voices in Physical Education and Youth Sport, Routledge: London.

Long, J. Hylton, K., Spracklen, K., Ratna, A. and Bailey, S. 2009. Systematic review of the literature on Black and Minority Ethnic Communities in sport and physical recreation. Sporting Equals and the Sports Council: London.

Lovell, T. 1991. Sport racism and young women. In G. Jarvie (Ed.), Sport Racism and Ethnicity. London: Falmer Press.

MacNeill, M. and G. Rail. 2010. The Visions, Voices and Moves of Young 'Canadians': Exploring Diversity, Subjectivity and Cultural Constructions of Fitness and Health. In J. Wright (Ed.). Living Physical Activity: Young People, Physical Activity and the Everyday. London: Routledge.

Markula, P. 1995. Firm but shapely, fit but sexy, strong but thin: the postmodern aerobicizing female bodies. Sociology of Sport Journal 12: 424-53.

McCaughtry, N. \& A. Tischler, 2010. Marginalized boys speak out: insights from school physical education for the obesity Crisis. In M. Kehler and M. Atkinson, Boys' bodies: speaking the unspoken. Oxford: Pater Lang.

Mowling, C., S.J. Brock and P. Hastie. 2006. Fourth grade students' drawing interpretations of a Sport Education soccer unit, Journal of Teaching in Physical Education, 25, 9-35.

O'Flynn, G. 2008. Young women, health and the self: the body, schooling, and the discursive construction of gendered and classes subjectivities. Saarbrucken: VDM.

Oliver, K., M. Hamzeh. and N. McCaughtry. 2009. Girly girls can play games/las niñas pueden jugar tambien: co-creating a curriculum of possibilities with fifth-grade girls. Journal of Teaching in Physical Education, 28, 90-110.

Oliver, K.L. and R. Lalik. 2000. Bodily knowledge; Learning about equity and justice with adolescent girls. New York: Peter Lang.

Parker, A. 1996. The construction of masculinity within boys' physical education. Gender and Education, 8, 141-158.

Phoenix, C. 2010. Seeing the world of physical culture: the potential of visual methods for qualitative research in sport and exercise. Qualitative Research in Sport and Exercise, 2(2), 93-108.

Pink, S. 2007. Doing visual ethnography ( $2^{\text {nd }}$ ed.). London: Sage.

Pink, S. 2009. Doing sensory ethnography. London: Sage. 
Pope, C.C. 2010. Got the picture? Exploring student sport experiences using photography as voice. In M. O'Sullivan and A. McPhail, Young People's Voices in Physical Education and Youth Sport, Routledge: London.

Prosser, J. 2007. Visual methods and the visual culture of schools. Visual Studies, 22(1), 13-30.

Ramanathan, S. \& P.R.E. Crocker. 2009. The influence of family and culture on physical activity among female adolescents from the Indian Diaspora, Qualitative Health Research, 19(4), 492-503.

Ratna, A. 2010. 'Taking the power back!' The politics of British-Asian female football players, Young, 18(2), 117-132.

Rail, G. 2009. Canadian youths' discursive constructions of health in the context of obesity discourse.. In J. Wright and V. Harwood (Eds.).Biopolitics and the 'obesity epidemic': governing bodies. Abingdon: Routledge.

Redelius, K., B. Fagrell. and H. Larsson. 2009. Symbolic capital in physical education and health: to be, to do or to know? That is the gendered question, Sport, Education and Society, 14: 2, 245 260 .

Rose, G. 2012. Visual methodologies: an introduction to the interpretation of visual methods ( ${ }^{\text {rd }}$ ed.). London: Sage.

Scraton, S, J. Caudwell and S. Holland. 2005. 'Bend it like Patel': Centring 'race', ethnicity and gender in feminist analysis of women's football in England, International Review for the Sociology of Sport, 40(1), 71-88.

Scraton, S. and B. Watson. 1998. Gendered cities: women and public leisure space in the 'postmodern city'. Leisure Studies, 17, 123-137.

Segal, L. 1997. Slow motion: changing masculinities changing men ( $2^{\text {nd }}$ ed.). London: Virago.

Shain, F. 2003. The schooling and identity of Asian girls. Trentham Books Limited, Stoke-on-Trent.

Shilling, C. 2008. Changing bodies: habit, crisis and creativity. London: Sage Publications.

Sporting Equals. 2007. Ethnic minorities, refugees and migrant communities: physical activity and health, Greater London Authority, 1_9. Available online at: http://www.sportingequals.org.uk/DynamicContent/Documents/BriefingPapers/Ethnic_minori ties_physical_activity_and_health_bri(1).pdf (accessed 20 July 2011).

Thangaraj, S. 2010. Ballin' Indo-Pak style: pleasures, desires, and expressive practices of 'South Asian American' masculinity, International Review of the Sociology of Sport, 45(3), 372-389.

Thomson, P. 2008. Doing visual research with children and young people. London: Routledge.

van Sterkenburg, J., \& Knoppers, A. 2004. Dominant discourses about race/ethnicity and gender in sport practice and performance. International Review for the Sociology of Sport, 39(3), 301321.

Vertinsky, P. 1992. Reclaiming space, revisioning the body: the quest for gender-sensitive physical education. Quest, 44, 373-396. 
Weedon, C. 1997. Feminist practice and poststructuralist theory (2 $2^{\text {nd }}$ ed.). Oxford: Blackwell.

563

Wellard, I. 2006. Able bodies and sport participation: social construction of physical ability for gendered and sexually identified bodies. Sport, Education and Society, 11, 105-119.

Wright, J. E. 1995. A feminist poststructuralist methodology for the study of gender construction in physical education: description of a study. Journal of Teaching in Physical Education, 15(1), $1-24$.

Wright, J. E. 2004. Analysing sportsmedia texts: developing resistant reading positions. In J. E. Wright, D. Macdonald \& L. Burrows (Eds.), Critical inquiry and problem-solving in Physical Education. London: Routledge.

Wright, J. 2006. Physical education research from postmodern, poststructural and postcolonial perspectives. In D. Kirk, D. Macdonald and M. O'Sullivan (Eds.), Handbook of physical education. London: Sage.

Wright, J. and L. Burrows. 2006. Re-conceiving ability in physical education: a social analysis. Sport, Education and Society, 11(3), 275-291.

Word count: 6904

Summary abstract:

Learning about the body in physical education, students often construct meanings based on their engagements with sporting or valued bodies in popular culture and media. The visibility of elite sports players in media, predominantly white and male, can affect the ideas that young minority ethnic women have about who can be sporty or active, and hence their own value within physical activity. Using visual methods, research was carried out with British Asian girls aged 13-14, who created photographs that represented their involvement in physical activity, and their ideas of which bodies are valued as sporting. Many girls placed their physical activity significantly in school, and saw sporting bodies as male and elite. At the same time, girls were physically activity outside of school despite not seeing themselves as sporty. Reflecting on the invisibility of minority ethnic women in sports media, this research suggests that greater representation may enable minority girls to see themselves as valued bodies as part of working to increase their engagement in sport and physical activity. 